\title{
ARENA FUTSAL UPAUJAYA DI KECAMATAN UPAU KABUPATEN TABALONG
}

\author{
Handrian Pranata Tetno \\ Program Studi Teknik Arsitektur Fakultas Teknik Universitas Lambung Mangkurat \\ handrian.pranata@gmail.com \\ Irwan Yudha Hadinata \\ Program Studi Teknik Arsitektur Fakultas Teknik Universitas Lambung Mangkurat \\ irwan.yudha@ulm.ac.id
}

\begin{abstract}
ABSTRAK
Olahraga merupakan salah satu aktivitas rutin yang dilakukan seseorang untuk menjaga kesehatan, Futsal menjadi sebuah tren pada kesenangan anak muda dan juga pada semua kalangan, olahraga futsal ini juga tidak berbeda dengan permainan sepakbola karena sama-sama dimainkan dengan cara ditendang ,perbedaanya hanaya futsal sangat mudah tidak memerlukan lapangan yang luas dan pemain yang banyak. Berdasarkan latar belakang permasalahan yang diangkat dari laporan ini yaitu bagaimana mewujudkan desain sebuah Arena Futsal (Indoor) Setara Tipe C yang rekreatif dan mempunyai profit di wilayah Kecamatan Upau. Metode yang dipakai untuk penyelesaian masalah ini yaitu metode perancangan merupakan metode penyelesaian masalah dengan konsep programatik. Metode perancangan adalah jawaban dari sebuah permasalahan yang nantinya mencakup kebutuhan dalam suatu bangunan. Dengan memfokuskan ke ruang, bentuk, fungsi, konstruksi.
\end{abstract}

Kata kunci :Arena Futsal, Kecamatan Upau, Metode Perancangan, Konsep Programatik.

\begin{abstract}
Sport is one of the routine activities that a person does to maintain health, Futsal becomes a trend in the pleasure of young people and also in all circles, futsal is also no different from the game of football because both are played by kicking, the difference is that futsal is very easy not to require a large field and a lot of players. Based on the background of the problems raised from this report, namely how to realize the design of a Futsal Arena (Indoor) Type $C$ equivalent that is creative and has a profit in the district of Upau. The method used to solve this problem is the design method is a method of solving problems with programmatic concepts. The design method is the answer to a problem that will encompass the needs in a building. By focusing on space, shape, function, construction.
\end{abstract}

Keywords : Futsal Arena, Upau Region, Design Method, Programming Concept

\section{PENDAHULUAN}

Olahraga Futsal pada saat ini menjadi olahraga yang sangat digemari oleh pemuda dan semua kalangan. Dikarenakan Futsal tidak hanya bisa dilakukan di arena terbuka, tapi juga bisa dilakukan di Arena tertutup. Maka tidak heran jika Futsal menjadi olahraga yang banyak diminati oleh semua kalangan. ada beberapa manfaat lain yang bisa didapatkan dari bermain Futsal. Antara lain yaitu meningkatkan kecerdasan dalam setiap memilih tindakan secara cepat dalam bermain sepakbola, meningkatkan kekuatan ketahanan tubuh saat menahan pemain lain, serta untuk pencegahan stres. Banyak pesepakbola profesional juga bermain 
Provinsi Kalimantan Selatan dibagi menjadi beberapa bagian Kabupaten, salah satunya yaitu Kabupaten Tabalong. Ibu kota Kabupaten Tabalong berada di Kota Tanjung. Dimana permainan Futsal menjadi olahraga yang banyak diminati oleh masyarakat di semua kalangan.

Banyaknya peminat Futsal ini bukan hanya di kota Tanjung saja melainkan di berbagai desa-desa, kecamatan di Kabupaten Tabalong, termasuk juga Kecamatan Upau.

Kecamatan Upau merupakan salah satu kecamatan di Kabupaten Tabalong, Provinsi Kalimantan Selatan, Terletak di bagian Timur Kabupaten Tabalong, memiliki luas $323 \mathrm{~km}^{2}$ dan berpenduduk 7.041 jiwa (2010) Jarak Kecamatan Upau dengan ibukota Kabupaten adalah $44 \mathrm{~km}$.

Besarnya peminat futsal di Kecamatan Upau ini terlihat dari berbagai acara-acara perlombaan yang diikuti seperti Futsal antar Kecamatan, Liga Pelajar, Namun besarnya peminat masyarakat terhadap Futsal tidak di imbangi dengan alat atau sarana yang memadai, Kecamatan Upau tidak mempunyai fasilitas Arena Futsal Indoor yang setara tipe $C$, hal ini sesuai dengan Peraturan Presiden Republik Indonesia Nomor 7 Tahun 2005, pada bab 30 menyatakan tentang program-program pembangunan dalam bidang peningkatan sarana dan prasarana olahraga.

\section{TINJAUAN PUSTAKA}

\section{A. Sejarah Dan Perkembangan Futsal Di Dunia}

Futsal pada awalnya didapatkan dari bahasa Spanyol yakni Futbol dan Sala, Futbol yang berarti sepak bola dan Sala yang berarti Ruangan, bila diartikan dalam kata lain maka artinya menjadi sepak bola dalam ruangan. Menurut FIFA Futsal berasal dari Montevideo, Uruguay pada tahun 1930. Orang yang pertama kali memperkenalkan futsal adalah Juan Carlos Ceriani, dia adalah seorang pelatih sepakbola yang berasal dari Negara Argentina. Futsal mulai diramaikan di seluruh Amerika Selatan bahkan dunia karena keunikannya, termasuk juga di Indonesia.

B. Sejarah Dan Perkembangan Futsal Di Indonesia
Di Tanah Air Futsal sudah dikenal sejak tahun 1998 - 1999, tapi secara resmi yang tercatat Futsal diperkenalkan di Indonesia pada tahun 2002.

\section{Perlengkapan Dan Peraturan Futsal Pemain}

Dalam olahraga futsal, pemain futsal berjumlah maksimal 5 orang, dari 5 pemain tersebut salah satunya menjadi penjaga gawang . dan cadangan pemain maksimal 9 orang.

\section{Wasit}

Wasit berjumlah 2 orang, terdiri dari wasit utama dan wasit pendukung. Wasit bertugas untuk memimpin jalannya pertandingan.

\section{Lapangan}

Lapangan futsal membentuk persegi panjang dengan panjang 25 - 42 meter dan lebar 15 - 25 meter.

\section{Durasi Permainan}

Permainan Futsal memiliki durasi bermain 2x20 menit, waktu istirahat 10 menit, lama tambahan waktu $2 \times 5$ menit.

\section{Bola}

Bola futsal memiliki 62 sampai $64 \mathrm{~cm}$ ukuran keliling bola, berat bola futsal dari 0,4 sampai $0,44 \mathrm{~kg}$ (nomor 4). Bola futsal memiliki lambungan sejauh 55 sampai $65 \mathrm{~cm}$. Bahan bola futsal dibuat dari kulit / bahan sintetik lainya.

\section{METODE PERANCANGAN}

Dalam arsitektur, Metode perancangan merupakan metode penyelesaian masalah. Metode perancangan adalah jawaban dari sebuah permasalahan yang nantinya mencakup kebutuhan dalam suatu bangunan. Dengan memfokuskan ke ruang, bentuk, fungsi, konstruksi.

1. Dasar Pemilihan Konsep

Konsep Programatik dipilih karena konsep perancangan ini didapatkan melalui kesimpulan analisis dan permasalahan arsitektur yang meliputi kesimpulan dari analisis lingkungan, kebutuhan, dan bentuk serta pemenuhan standar dan regulasi yang 
dituangkan dalam skema konsep perancangan yang mampu menyelesaikan permasalahan arsitektur pada desain Arena Futsal Upaujaya di Kecamatan Upau.

Pengumpulan data diperlukan untuk mengetahui standar-standar ruang dan hal-hal yang diperlukan untuk gedung olahraga. Data yang dikumpulkan sendiri dari, buku, artikel, jurnal dan media-media lainya. Pengumpulan data ini juga sebagai penyelesaian masalah arsitektur.

2. Pengertian Programatik

Merupakan konsep yang menyelesaikan satu atau beberapa masalah tertentu yang nyata dan terukur. Konsep ini dikembangkan berkisar persoalan-persoalan yang pragmatis dan yang diidentifikasi dari program sebuah bangunan. Konsep ini tercapai dari tanggapan langsung dari pemecahan masalah.

\section{A. Konsep Programatik}

Programatik Merupakan rangkaian gagasan ide - ide yang menjadi acuan dalam proses perancangan. Konsep programatik mempunyai fungsi sebagai solusi pemecahan masalah desain.

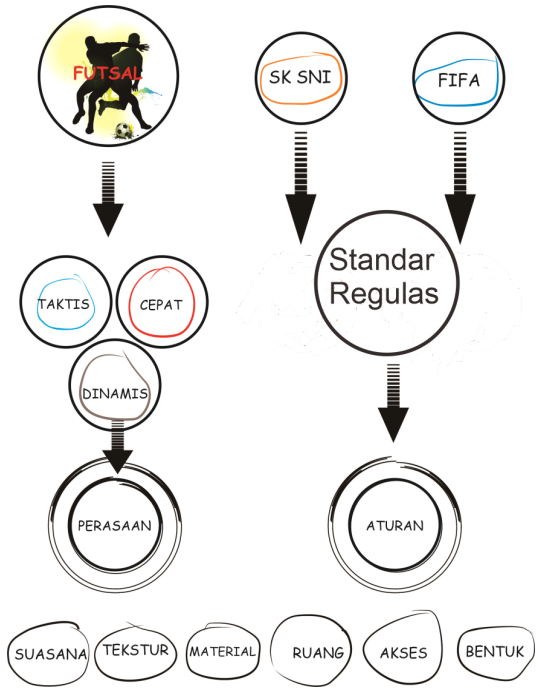

Gambar 1. Konsep Programatik

Futsal merupakan Olahraga yang memerlukan daya tahan tubuh yang kuat, di samping itu juga olahraga futsal memiliki sifat yang cepat, harus bisa berpikir taktis, selain itu juga olahraga ini selalu bergerak dinamis dan memicu tubuh juga bekerja dari dalam untuk meningkatkan suasana hati.

Berikut adalah pengaplikasian desain dari konsep Programatik, yang keluaranya memunculkan ide - ide yaitu suasana, Tekstur, Material, Ruang, Akses, dan Bentuk sebagai berikut:

\section{Suasana}

Olahraga memicu tubuh juga bekerja dari dalam untuk meningkatkan suasana hati. Olahraga intens dapat memicu otak melepaskan neurotransmitter yaitu hormon endorfin. endorfin bertugas mengirim pesan kepada tubuh untuk menghilangkan rasa sakit dan juga mengurangi stres.

Olahraga secara intens membuat suasana Seseorang menjadi lebih bersemangat. Karena efeknya membuat suasana hati lebih bahagia, olahraga menjadi "antidepresan" untuk menangani depresi dan kecemasan pada

\section{Tekstur}

Tekstur dari sebuah lapangan Futsal dapat menentukan nyaman atau tidaknya bermain, dalam kasus Arena Futsal Upujaya ini memasukan Konsep tekstur

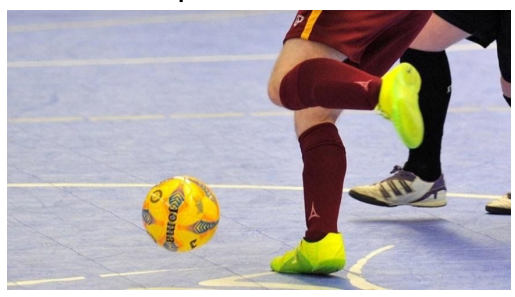

Gambar 2. Tekstur Lapangan

Sumber: karpetlapangan.co.id/tag/sahabat-futsal/

Di Dalam Permainan Futsal kita dituntut untuk selalu bergerak Taktis, cepat, dinamis maka dari itu, di rancanglah sebuah Lapangan Futsal yang memiliki tekstur Permukaan tidak licin dan relatif kesat.

\section{Tekstur Lantai lapangan futsal karpet plastik} Material

Lantai Interlock

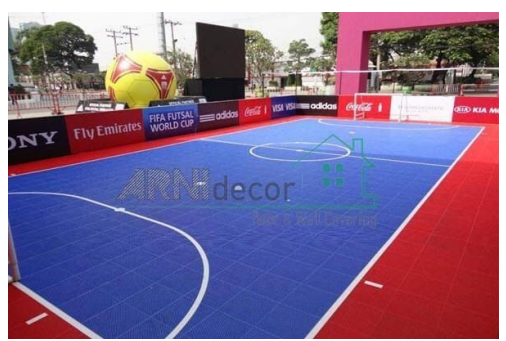


Gambar 3. Lantai vinyl

Sumber:

https:/larnidecor.com/kenali-3-jenis-pelapis-lantai -lapangan-futsal.html

Dalam kasus Arena Futsal Upaujaya diterapkan dengan jenis ketiga lantai Interlock dengan jenis bahan karpet plastik.

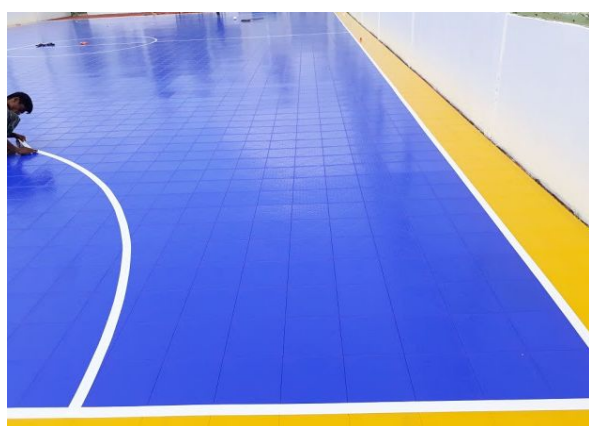

Gambar 4. Jenis Lapangan Futsal Karpet Plastik Sumber:

https:jasapembuatanlapangan.id/lapangan-futsalinterlock.

\section{B. Konsep Ruang}

Konsep ruang disini mengikuti aturan Gedung Olahraga Yang setara Tipe C Sifat ruang dan hubungan Ruang SIFAT RUANG HUBUNGAN RUANG
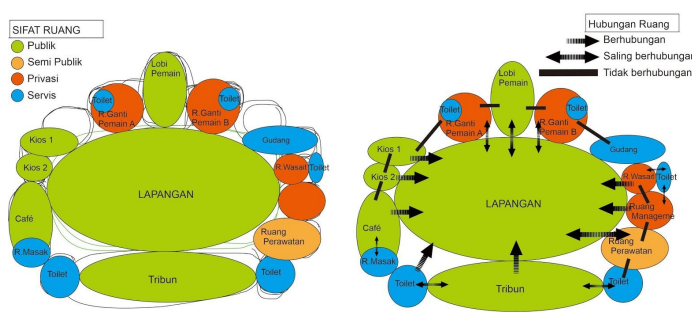

Gambar 5. Sifat Ruang

\section{Prinsip Sirkulasi ruang}

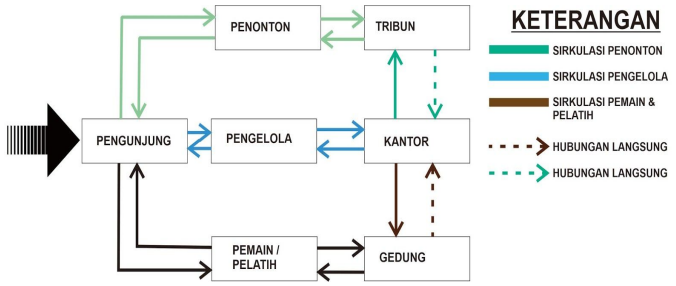

Gambar 6. Organisasi Ruang

\section{Besaran ruang}

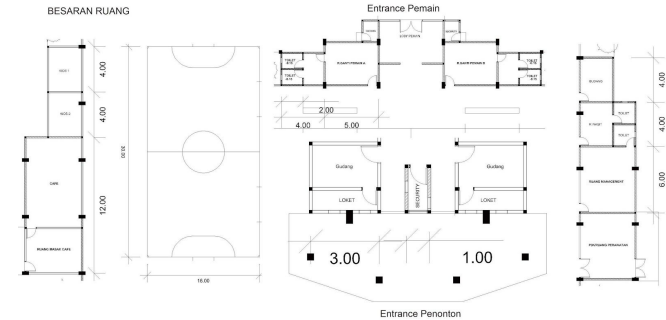

Gambar 7.Besaran Ruang

Sifat ruang memiliki empat jenis ruang yaitu Publik, Semi Publik, Privasi, Servis.

- Ruang Publik : Lobi Pemain, Lapangan, Tribun, Café, kios1,kios2

- Ruang Semi Publik : Ruang Perawatan, Gudang

- Ruang Privasi : Ruang Ganti A, Ruang Ganti B, Ruang Wasit, Ruang manajemen

- Ruang Servis : Toilet, Ruang masak Hubungan Ruang memiliki tiga jenis hubungan yaitu berhubungan, saling berhubungan, tidak berhubungan.

- Berhubungan :R.wasit, ruang manajemen, tribun, toilet, café, kios1, kios2.

- Saling berhubungan : Lobi pemain,R.ganti pemain A, Ruang ganti pemain $B$, Toilet,tribun.

- Tidak Berhubungan : R.ganti pemain A,Lobi Pemain, R.ganti pemain B, R.wasit, R.management, R.peralatan (P3K), toilet, kios 1, kios 2.

\section{Sirkulasi ruang}

Sirkulasi Penonton dan Pemain dipisahkan menjadi dua

Sirkulasi Penonton

- Entrance - Loket - Security - Lorong - Tribun

Sirkulasi Pemain

- Entrance - Lobby Pemain - ruang ganti - bench pemain - Lapangan ruang ganti - Toilet.

$\cdots$ ang

Ruang café $5 \times 8$ m2 - R.masak Cafe $5 \times 4 \mathrm{~m} 2$ - kios $3 \times 4 \mathrm{~m} 2$ 
- $\quad$ Ukuran Lapangan 30x16 m2

- Entrance Pemain

Toilet 1.50x2 m2 - R.Ganti Pemain 5x4 m2

- Entrance Penonton

Toilet 1.50x2 m2 - Loket 3x1 m2 - Gudang $3 \times 2 m 2-$ security $1 \times 2 m 2$

\section{Akses Ruang Luar}

Akses Yang diterapkan ke Site , 1 jalur dan Memiliki 2 akses yaitu akses penonton dan akses pemain, di bagian barat sisi depan Gedung olahraga untuk Penonton dan akses bagian timur untuk Pemain dan official tim, Di bagian sisi utara untuk pengantaran barang ke café .

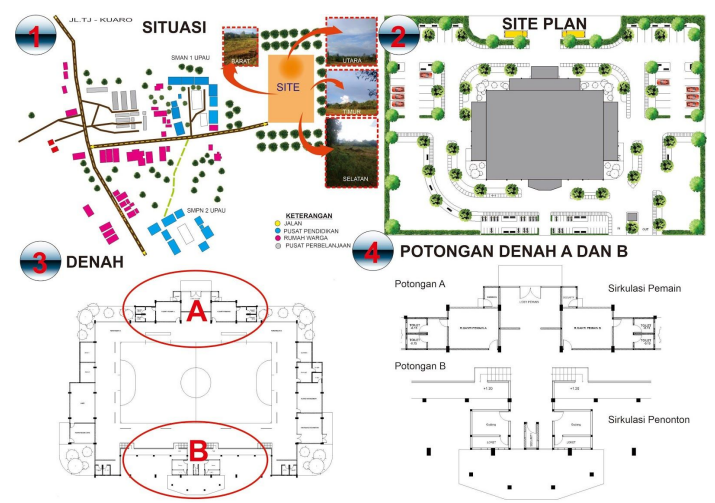

Gambar 10. Akses site

Tapak berada jl.MTQ RT.IV No 109. Lokasi tapak di sekitar Pusat pendidikan dan Pusat Perbelanjaan. Pada sisi barat site menjadi tampak depan karena sirkulasi ke arah site hanya satu. Sisi utara site kebun karet warga. Sisi Timur site Hutan warga. Sisi Selatan site Kebun karet warga

Jalan keluar dan Masuk ke site hanya ada satu untuk mempermudah Penjagaan, maka dibuatlah POS Jaga di tengah - tengah antara Jalan keluar dan masuk. Di setiap sisi jalan dibuat pedestrian untuk mempermudah pejalan kaki ke bangunan dan juga ditambahkan Vegetasi sebagai peneduh dan Pengarah jalan.

Akses ruang ke site memiliki empat akses yaitu yang Pertama akses penonton yang berada pada sisi barat bangunan, yang kedua, akses untuk Pemain yang berada di sisi timur bangunan yang ke tiga, Penyuplai Logistik barang ke kafe berada di sisi utara bangunan, akses darurat, kesehatan dan akses ruang pengelola berada di sisi selatan bangunan.

\section{Akses Ruang Dalam}

\section{Akses Penonton dan Pemain}

Akses menuju Ruang dalam memiliki dua akses yaitu akses penonton melalui sisi bagian barat untuk penonton, akses kedua berada di sisi timur untuk Pemain, Ofisial Tim dan wasit.

\section{Akses Antar Ruang}

Akses antar ruang dibagi menjadi dua yaitu akses penonton dan pemain,ofisial tim dan wasit. akses untuk penonton berada di depan bangunan atau di sisi barat bangunan,yang pertama penonton mengantri di loket untuk mendapatkan tiket lalu melewati pengamanan/security lalu melewati lorong di bawah tribun penonton.

\section{E. Konsep dan Desain}

\section{Konsep Bentuk}
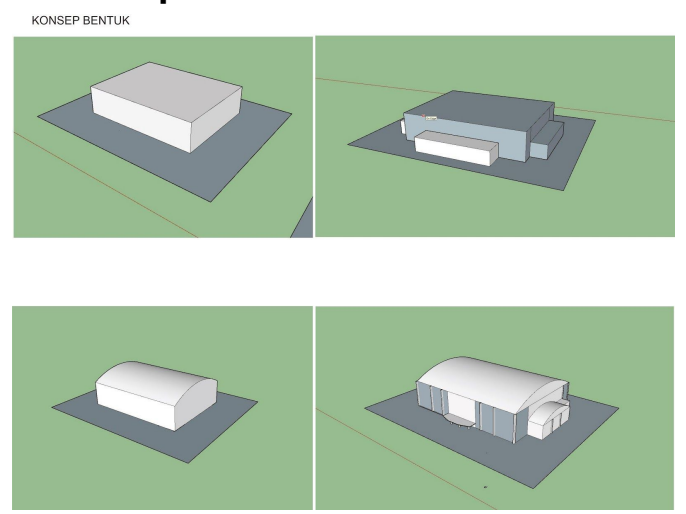

Gambar 11. Konsep bentuk

Konsep Bentuk mengambil bentukan kubus karena bangunan hanya satu masa dan bangunan terpusat . transisi bangunan dari bentukan masa besar ke masa kecil di aplikasikan ke atap arena futsal, mengecil di bagian atap bagian samping dan bagian belakang . di bagian depan dirancang berbeda dengan bentuk - bentuk sebelumnya. Bagian memperindah suatu bangunan agar lebih menarik. 


\section{Konsep Landskap}

Konsep Lansekap Penambahan vegetasi pada bagian depan site dimaksud untuk menyerap sinar matahari langsung, vegetasi ini juga berfungsi untuk pengarah jalan dan peneduh

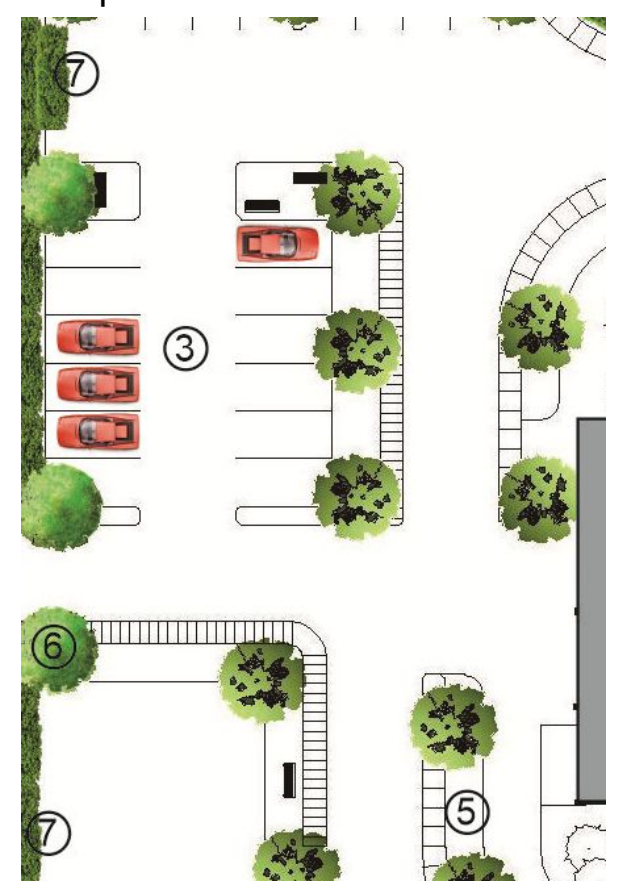

Gambar 12. Konsep View

Selain penggunaan vegetasi pada area parkir, juga digunakan untuk penataan lanskap ruang luar pada area Pedestrian. Vegetasi ditata dan menimbulkan kesan menarik.

- Vegetasi yang di gunakan si site yaitu :

- Vegetasi Peneduh

- Vegetasi Pengarah Sirkulasi/jalan

\section{Konsep Tata Sirkulasi Luar Bangunan}

a. Parkiran Motor

Parkiran pengunjung kendaraan bermotor berada di sisi barat, persis di depan penerima utama.

b. Entrance/ Jalan masuk Penonton

c. Area Hijau

Area hijau berada di Barat Laut dan Barat Daya sisi bangunan

d. Parkiran Mobil
Parkiran pengunjung Mobil di sisi utara dan selatan massa bangunan.

e. Parkiran Bus dan Parkiran Pemain

Parkiran pemain di pisah dengan pengunjung untuk keamanan dan kenyamanan pemain, dan mempermudah pemain keluar masuk Gedung, berada di bagian timur massa bangunan.

f. Entrance/ Jalan masuk Pemain Berada di bagian barat massa bangunan.

g. Massa bangunan

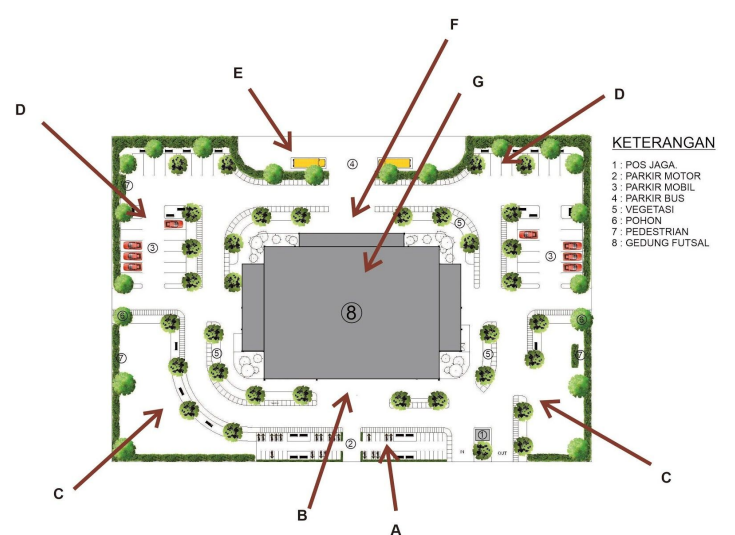

Gambar 13. massa Bangunan

\section{Konsep Tata Sirkulasi Dalam Bangunan}

Konsep sirkulasi ruang dalam Gedung Arena Futsal Upaujaya menggunakan sirkulasi terpusat. Semua kegiatan yang dilakukan pada Bangunan gedung mengarah ke Lapangan Futsal.

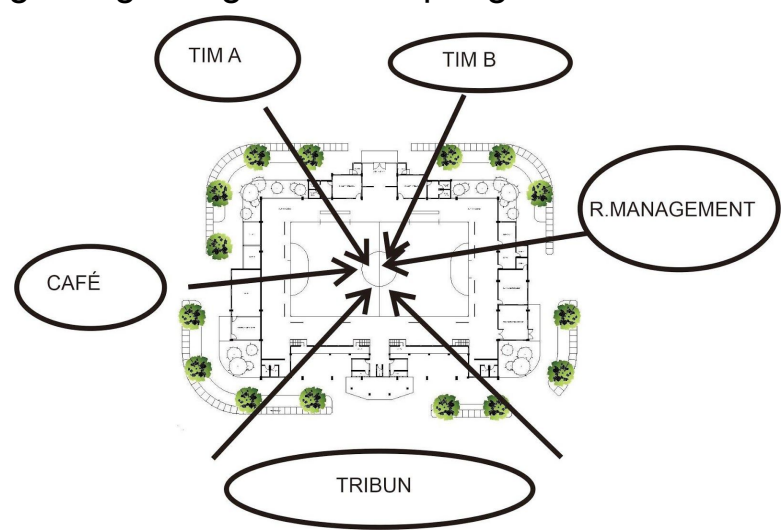

Gambar 14. Konsep Sirkulasi 


\section{Desain Struktur}

Struktur bagian bawah menggunakan pondasi tapak

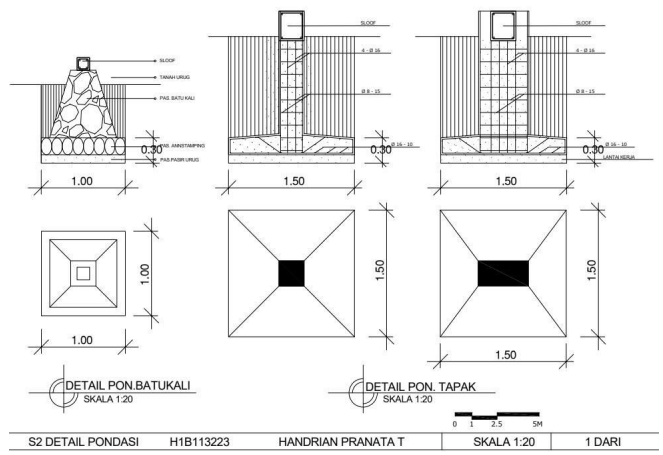

Gambar 15. Pondasi tapak

Kolom dan Balok

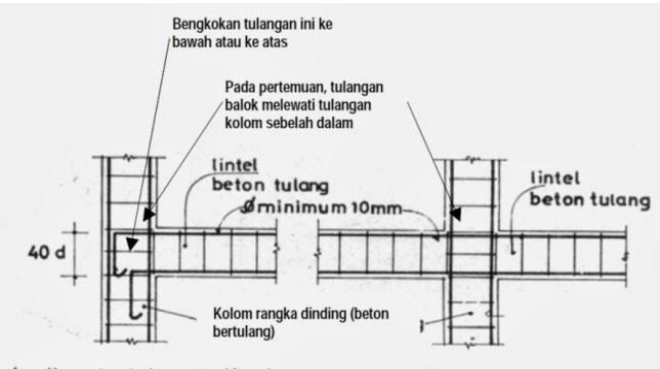

Gambar 16. Kolom dan balok

Sumber:ainlahay.blogspot.co.id/2013/12/bangun an-gedung-tahan-gempa-untuk.html

Struktur Atas

Bentukan atap bangunan menggunakan struktur space frame, bentuk rangka atap ini cocok untuk bangunan bentar lebar.

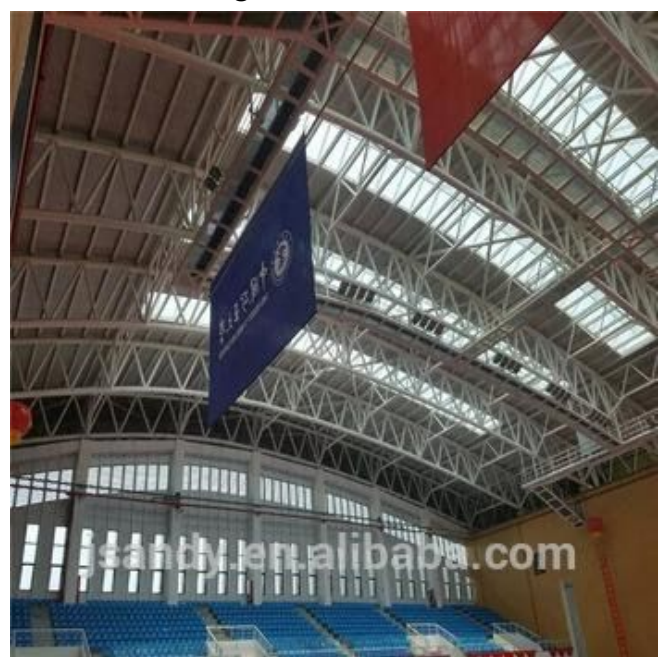

Gambar 17. Struktur atap space frame

\section{Konsep Utilitas}

Sistem Air bersih

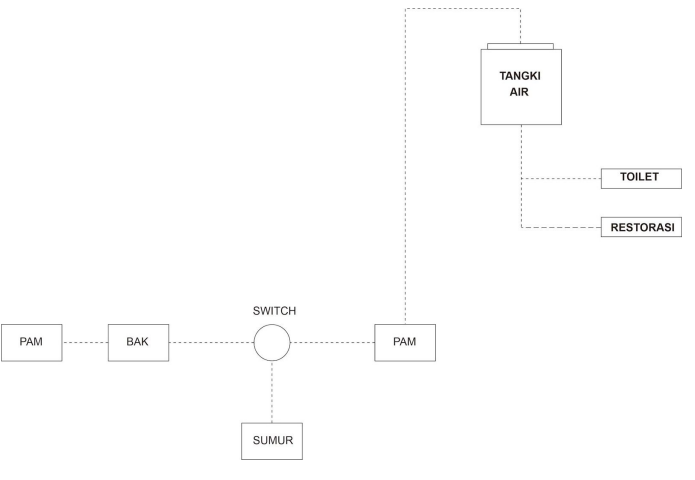

Gambar 17. Sistem dari Air Bersih Drainase

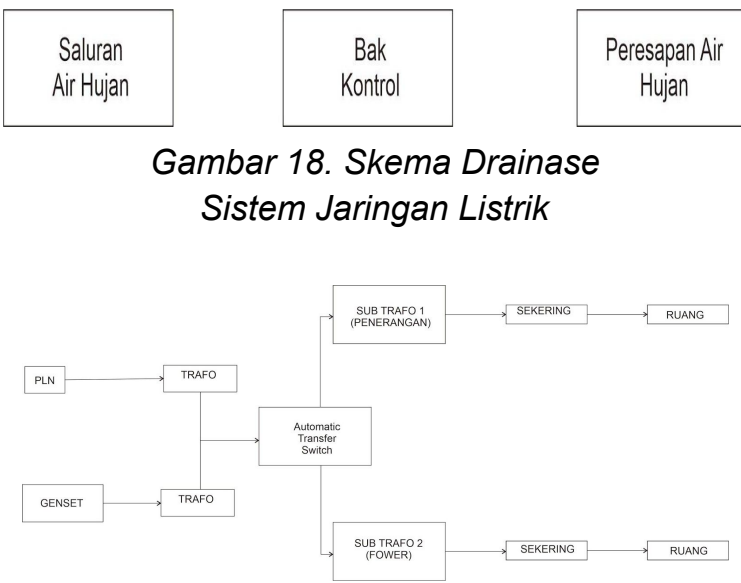

Gambar 19. Skema Jaringan Listrik

\section{KESIMPULAN}

Dalam perancangan sebuah Arena Futsal Upaujaya di Kecamatan Upau Kabupaten Tabalong yang baik, diperlukan fasilitas-fasilitas yang dapat mewadahi semua aktivitas para Pemain,pengelola, penonton dll. Dengan adanya Gedung Futsal di Kecamatan Upau Kabupaten Tabalong diharapkan para pemain dapat terus aktif mengembangkan skill permainan, strategi dan bisa berpikir cepat dan taktis. Adapun permasalahan yang dihadapi yaitu Bagaimana bentuk rancangan sebuah Arena Futsal (Indoor) Setara Tipe C yang Rekreatif dan Mempunyai Profit di kecamatan Upau. 


\section{DAFTAR PUSTAKA}

$\begin{array}{ccc}\text { Dasar-dasar Arsitektur: } & \text { Konsep } \\ \text { Perancangan Arsitektur. } & (2018,58) \text {. } \\ \text { Diambil } & \text { kembali } & \text { dari } \\ \text { annasmaulana.blogspot.co.id: } & \end{array}$

Mini Football Square di Kota Pontianak.

(2018, mei 8). Diambil kembali dari media.neliti.com:

https://media.neliti.com/media/public ations/189308-ID-mini-football-squar

e-di-kota-pontianak.pdf

Peraturan Resmi FIFA. (2018, Mei 8). Diambil kembali dari wowtopik.com: http://www.wowtopik.com/t352--Perat uran-Resmi-Permainan-Futsal-FIFA-t erbaru-lengkap

PRAGMATIK; KONSEP DASAR MEMAHAMI KONTEKS TUTURAN. (2018, 5 8). Diambil kembali dari www.researchgate.net:

https://www.researchgate.net/publica tion/283403378_PRAGMATIK_KON SEP_DASAR_MEMAHAMI_KONTE KS_TUTURAN

Tinjauan umum gedung olahraga futsal. (2018, 5 6). Diambil kembali dari e-journal.uajy.ac.id:

http://e-journal.uajy.ac.id/2071/3/2TA 10825.pdf

upau, Tabalong. (2018, mei 8). Diambil kembali dari id.wikipedia.org: https://id.wikipedia.org/wiki/Upau,_Ta balong

https://www.masterpendidikan.com/2017/08/ sejarah-permainan-futsal-dunia-dan-i ndonesia.html

https://decorindoperkasa.com/jual-vinyl-sport I 